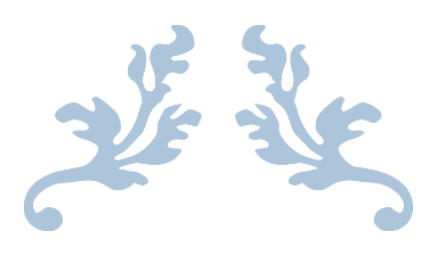

\title{
`I LEARNED ALL ABOUT LIFE WITH A BALL AT MY FEET': COACH CARTER AS A \\ REFLECTION ON THE SPORTS - ACADEMICS DEBATE AND EDUCATION
}

HO MANH TOAN

11413016 
'I learned all about life with a ball at my feet': Coach Carter as a reflection on the sports academics debate and education

\begin{abstract}
How does Coach Carter (Carter, 2005) reflect the debate between sports and academics in reality? The research examines the case of a sports movie Coach Carter, which possesses many characteristics of the education film genre but has often been excluded from the academic realm. This exclusion reflects a debate on sports versus academia and the priority of academics in an education system. The film follows formulas of a conventional sports film but creates its main conflict around sports - academics tension with the spirit of an education film. In conclusion, Coach Carter denies supporting the myth that success can be easily found in sports and advocates for a balance between sports and academics.
\end{abstract}

\title{
KEYWORDS
}

Education; cinema; film; movie; sports; academic; school; Coach Carter. 


\section{ACKNOWLEDGEMENT}

Upon the finish and submission of this thesis, I would like to express my gratitude to my advisor Professor Joseph Progler for his guidance, suggestions, and advice since the beginning until the finishing of this thesis. 'A teacher like you cannot be found'.

I would like to thank my older brother Ho Manh Tung and his wife Nguyen Hong Kong, my friend Nguyen Hai Phong for their feedbacks in the editing process. In addition, I would like to express my appreciation to my friends Nguyen Ngoc Phu, Yuki Ueno, Phung Anh Hao, Hoang Minh Dong, Pham Tran Hai, Dang Minh Phuong, and Nguyen Viet Dung for their mental support and great friendship throughout the years of college and the intense period of writing.

I would like to thank my fellow seminar students, especially to Hoyri Mohamad, Kevin Fauzi, and Anandya Kurniawan for their wisdom, encouragement, and friendship.

I am also grateful to Professor Peter Mantello and Professor Joseph Hicks for their inspiration in learning and writing.

Nevertheless, I am forever in debt with my father Ho Sy Tiep and my mother Nguyen Thi Minh for their unconditioned supports, love, faith and continuous encouragement throughout my years of study.

This accomplishment would not have been possible without them. Thank you.

Author,

HO Manh Toan 
PART I

INTRODUCTION TO THE SPORTS EDUCATION AND THE SPORTS AND ACADEMICS

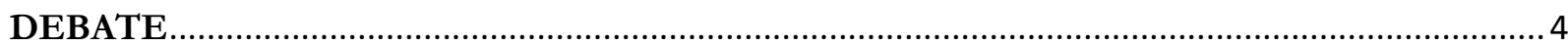

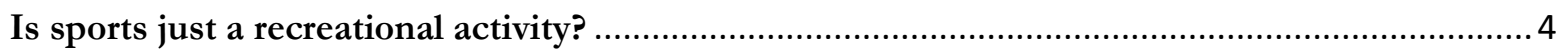

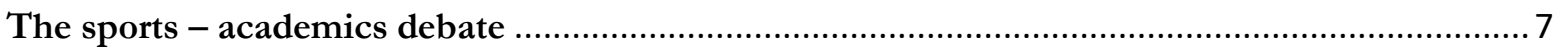

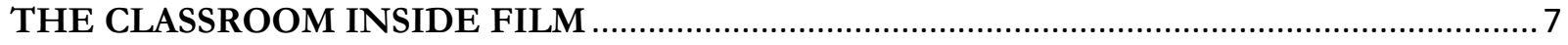

WHAT DID THEY SAY ABOUT EDUCATION FILM? .................................................... 10

PROBLEMS IN EDUCATION MOVIE THAT CAN EXPLORE FURTHER ...........................13

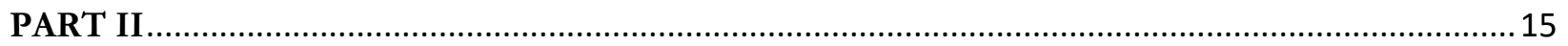

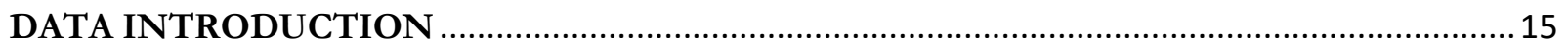

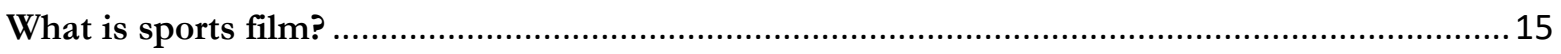

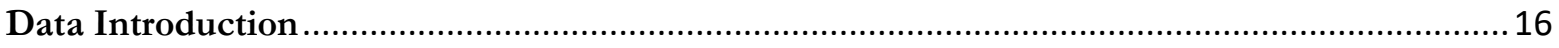

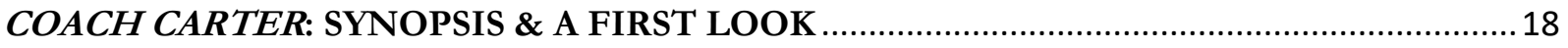

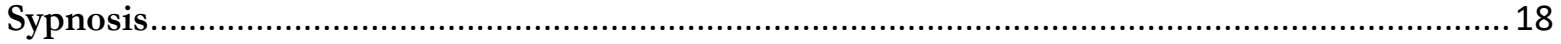

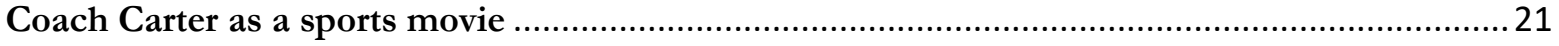

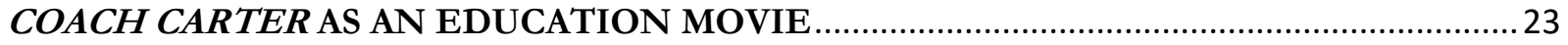

COACH CARTER AS A REFLECTION ON SPORTS - ACADEMICS DEBATE AND

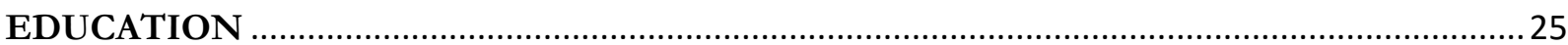

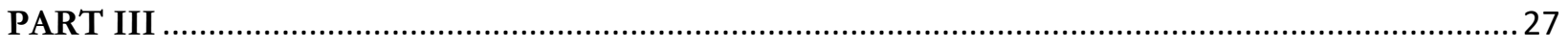

CONCLUSION

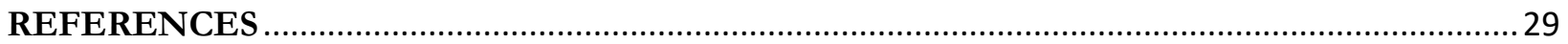

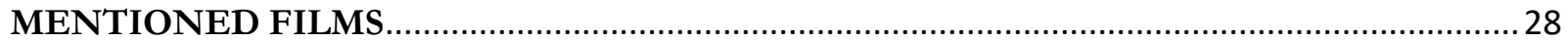




\section{PART I}

\section{INTRODUCTION TO THE SPORTS EDUCATION AND THE SPORTS AND ACADEMICS DEBATE}

The school is a close to the heart experience that virtually every person has been through. When such an experience is depicted on a cinema screen, we often feel as though we were traveling back in time and could empathize with what was showing on the screen. Such is the case when I watched Coach Carter (Carter, 2005). Although I went to a Vietnamese high school whose experience was vastly different from the American customs, I understood the students' experiences in Coach Carter: how hard it was to keep up with the training and studying at the same time. Still, when I went through all of that, I am glad that I had to face both the physical and mental challenges to be who I am now.

Carrying an understanding from the experience, I want to explore the idea of education and also the idea of sports education through the cinematic representation of Coach Carter. More specifically, how does Coach Carter reflect the debate between sports and academics in reality? What does Coach Carter say about the idea of education? From the movie alone, there are many aspects that we can discuss and they tell how movie and reality connect together, but firstly, the research will review the reality of sports in the education system and the sports - academics debate.

\section{Is sports just a recreational activity?}

The conventional belief views sport as a physical and health practice rather than the training of the morality or the mind. Albert Camus once said: "After many years during which I saw many things, what I most surely about morality and the duty of man I owe to sports.” (The School of Life, 2015). His statement stresses on the influence of sports on morality but if we replace "sports" for "education", will it still be the same? In a way, sports or academic subjects do train people in a specialty, but what lies beneath is the education of human. For instance, sports is usually an extracurricular activity in school and the benefit is often recreational. Besides club activities, a school team can provide a serious training environment for a targeted number of students who have abilities and the purpose of joining tournaments and bringing victory for the school. In this case, the environment can be as serious as a professional environment but the goal is usually short-term and individually speaking, a career in sport 
is rarely something that a student-athlete aims for. Inside the school, sport or physical education is a subject but not in the educational sense like math or literature.

Can sport do any better than school at the aspect of educating people? Most of us barely see sports anything than a form of entertainment. However, it is surprising that there are aspects that we can consider in sports more educational than usual assumptions. Steel (1977) suggested that a sportsman learns a physical action by doing it wrong many time until he adjusts his body to perform the action right, then he internally and unconsciously plays not only the actions but also rules and tactics in the game. In a way, every sports game is the same but different in nature because a player does not do the same thing in every game but he indeed creates new things based on their own understanding of the game. Those who play sport acquire a level of physical literacy that can influence their minds as the old saying "A sound mind in a sound body". Plato strongly included sport in term of gymnastic as an important part of his education system: "And what shall be their education? Can we find a better than the traditional sort? - and this has two division, gymnastic for the body, and music for the soul" (Plato, 1945). However, Plato idea is more about the balance between mind and body rather than insisting on that practice of sport or gymnastic can actually produce moral value; and it was fairly recent "that the practice of rule-governed team sports conduces to the development of cooperation and some sense of justice as fair play" (Carr, 2010, p. 6).

In the modern education system, sports are irrelevant to the education of the mind. Sir Ken Robinson (2006) suggested that there is a hierarchy of subject in education system around the world, which basically was built to serve industrialism, with mathematics and languages on top, then humanities, and finally arts, at the bottom; and the public education was built upon two ideas: what is essential for work and what is required for college. Hence, we have a system highly emphasizes the importance of academic as our main mode of education since the 19th century. Nonetheless, the society's demand remains unchanged leads to the consistency of education system. Sports are still an extracurricular activity or even if it is included in the curriculum, it has a limited time on the schedule. The modern education system has been being criticized against by many scholars. In Deschooling Society, Ivan Illich (2002, p. 1) said: "The pupil is thereby "schooled" to confuse teaching with learning, grade advancement with education, a diploma with competence, and fluency with the ability to say something new". At the age of 6, we start schooling and step by step, we escalate throughout the system by the determination of grade, test results and certification from the authority. Hence, the 
common sense is, you passing through school with the excellent certificate, you are being perceived as a smart person. Moreover, once you graduate from school, the emphasis on the word "learning" will become different. The diploma gives a person a sense of completion, the permission to stop learning about something because you are certified. Gatto (2005) put these perceptions into 7 lessons: confusion, class position, indifference, emotional dependency, intellectual dependency, provisional self-esteem, once can't hide. Robinson (2011) considers what has been taught inside the school as an academic illusion: when the academic abilities are being mistaken for intelligence; this lead to a paradox when "producing a work of art doesn't often count as appropriate intellectual work in an arts departments" (Robinson, 2011, p. 105).

Robinson (2011, p. 106) said: "If you wanted a degree in art, you had to go to university and study the history of art. You didn't create art at university; you wrote about it." A person does not receive a degree when he graduates from a sports academy, he either has a career in sports or he has to switch and learn something else. However, there is a clear difference between making art and playing sport; and the most visible difference is art results in a tangible product but not sports. There is only a few characteristic that people often talks about when mentioning sport's benefit in academic. For instance, Stephen Baddeley, director of sport at the University of Bath, shared that: "The mind wanders when doing essays, but if you develop a focus and know you have to use your time efficiently then it's a very transferable skill" (Cited in Gill, 2014). Moreover, according to Bowen and Greene (Cited in Bowen \& Hitt, 2013), they found no negative relationship between sports participation and academic achievement, in fact, the "measures of a school's commitment to athletics are significantly, positively related to lower dropout rates as well as higher test scores".

The disconnection between sport and academic is the result of the debate whether sports contribute to the education of the mind or not. In reality, there are many reasons leading to the insignificant role of sport in academic. Firstly, public education was not established for everyone but for the need of the society. John Dewey (1916) explained: "Education, in its broadest sense, is the means of this social continuity of life." The demand of the society will define the need for education. Hence, in an industrialized and globalized society as we are living in, there is a higher emphasis on subjects like science or language. Secondly, as art or music, sports is naturally designed for a small percent of the population so it leads to the establishment of a specialized institution which stands outside of the academic paradigm and the education system. Finally, regardless of its educational aspects, there is no 
tangible way to evaluate a sportsman as easily as the way our current linear education system evaluate students.

\section{The sports - academics debate}

In reality, high schools in the United States have been facing the same question of priority: sports or academic. Amanda Ripley (2013) argued that the United States has been spending too much on high school sport and sport is negatively affect high school study environment. On the other hand, Bowen and Hitt (2013) argued that both sport and academic success require focus and dedication, thus, the success in one field will likely to benefit the other. Those who against sports, like Earl Smith (2014) argued that sport shifts the priority and energy of school from study to endless preparations and displays. Those who support sports, like Stephen Bradley (Quoted in Gill, 2014) argued that: “Their weeks are very pressurised, so top sportspeople are extremely organised, disciplined and efficient with their time, which are useful skills in the academic side of their lives."

The debate is the result of a well-known myth that sport can be the way to richness and social class, especially to minority populations. They prioritize sports over the school thinking they will make a living while doing what they love. However, a career in sports means a person, who should be talented, is necessarily in the system of a specialized academy or youth club from the young age and they can expect to have a professional contract when they are 18. A career in sports also relatively short and risky because the risk of injury is high, and at the age of 30, a person's physical condition will not be able to perform as good as it used to be and the retirement is expected. Professional sports career is a rare chance but can be ended abruptly. Regardless the rarity, sports is still dominant in many high school students' mind because the culture in America ritualize sports as a cultural event that the whole town will not going to miss. As long as sports is the main event on campus, studying should come later.

\section{THE CLASSROOM INSIDE FILM}

The debate caught the news media attention in 2013 - 2014 but the issue of sports and academics particularly and education generally has become famous materials for cinema. For instance, Friday night lights (Berg, 2004) depicted a dramatic high school football season in a small town where not only the 
kids but also the adults were heavily involved. Away from the sport, according to Trier (2001), there are over one hundred school films - which he considered all movies talk about teachers and students. He employed school films as a reflective exercise in his teacher training program. The main purpose, for Trier, was to describe, reflect and study the relationship between the private and professional life of the movie teachers. For instance, a pre-teacher noted that the movies created the idea of superhuman teachers who have no personal lives, are work addicts and can do whatever they want. Moreover, there is a reflection through the film This is my father (1998) which a pre-teacher recognized how the main character became a teacher because of the connection with personal life, which can be true for almost every teacher. The author believed that there are many points in the movies that can be studied and they can be an important source for educators to reflect on or prepare themselves for the real-life situations. Cohen (Quoted in Trier, 2001, p. 139) suggested that:

[School films] provide encounters with teachers, parents, and adolescents and a thick description of ... schools that histories of education cannot even approximate. We have not begun to exploit the possibilities of film. There is a rich archive waiting for the historians of education to explore in film.

Cohen's remark once again reminds us how powerful a movie can be. Film is one of the most powerful forms of artistic expressions. In a film, you can find collective efforts of script, music, lighting, cinematography, acting, directing, editing and so on that make up memorable moments. The renowned film critic Roger Ebert (2005) argued that movie can put us in another person's shoes with the full capability of letting us feel what they feel. Movie is all at once heartbreaking, epic, dramatic or even scary. Moreover, a movie is also highly related to the time when it was made, which makes it significantly distinct in style and ideology. For instance, movies made in the 50s will provide different perspectives from the movies made in the $90 \mathrm{~s}$, even though they share the same plot. Thus, in term of education films, there are two subsets which represent two different points of view: educators or students.

As both of the subsets are about education, some similarities are worth examining. First of all, they mainly tell a story about student's progress. Regardless of whether the movie is told from a student or a teacher's perspective, what we expect to see in these movies are the growing up process of the youth. Secondly, the school system is often portrayed through a villain who is too conservative, rigid and 
bureaucratic. There is the principal Ed Rooney in Ferris Bueller's day off (1986), there is Mr. Nolan in Dead poets society (Weir, 1989) or Mrs. Campbell in Freedom writer (2007). Finally, as Reed (2001) suggests the genre heavily relies on "automatic identification and recognition" places and persons, such as the gym, the classroom or the cool teacher, the nerd.

Some of the most famous student's point of view movies are Dazed and confused (Linklater, 1993) or The breakfast club (1985). Most of these movies usually portray students and their struggling in school. The depiction of teachers in these films is biased and they usually take the role of the main antagonist like the principal Ed Rooney in Ferris Bueller's day off or the disciplinarian Richard Vernon in The breakfast club. Regardless of being set solely in school, these movies focus more on out-of-school experiences, like Dazed and confused talked about how all four grades of a high school partied together on the last day of the academic year. Farber and Holm (1994b, p. 21) emphasize that these movies "construct narratives around images and ideas about the relationship of adolescent freedom and school experience."

Another subset of movies on education is the educator-heroes movies, referred to by Farber and Holm (1994a). These movies tell the story of an educator-hero who comes to a struggling class and changes it for good. Some of the best examples are Stand and deliver (Menendez, 1988) or Lean on me (1989). These movies usually deal with minorities like Hispanic or Black students, who are usually disinterested in school, within an inner city school setting. However, there are different cases like Dead poets society which took place in a preparatory school, where students are elite and aiming for Ivy League universities. Farber and Holm (1994a) argue that these movies only engages with the audience through shallow and partial portrayals of the whole relationship of school, teachers, and students; there are some emotions but they usually lack depth.

The learning can vary in places and methods, but the act of teaching - which requires teachers and students - always happens inside the school environment. The locations in student movies like Dazed and confused or Ferris Bueller's day off vary from a party to a diner, from a school football field to the street of Chicago. The breakfast club is a difference when it took place mainly inside a school library, however, the students were there due to detention but not for class. On the other hand, the class in Dead poets society or Stand and deliver is memorable with its own characteristic. The most heartfelt moment in Dead poets society happened inside a classroom when students paid tribute to their poet 
teacher John Keating (Robin Williams) by standing on the table and saying "Oh Captain, My Captain" aloud. Stand and deliver mostly happened inside the classroom with extensive courses from Algebra to Calculus. While the outside classroom education is highly personal and subjective, with different impacts a case by case basis, the inside classroom education is more universal and relatable. For those who have been through school, the memories of an inspiring teacher, a best friend or an unforgettable lesson will always linger on.

The cinematic study tells us more than mere technicality or denotation. Through the careful analysis of a set of movies or a movie, we hope to reflect on the ideology that it brings, to find out the hidden message that it sends, or an unexpected possible hidden secret within the frames. In a sense, a film researcher is a detective on 221B Baker Street who is in a room full of tobacco smoke trying to eliminate all the impossibility and find out the final answer. Liston and Renga (2015) stress that through different depiction and settings in education film, we can raise some questions regarding aspects of education and put them under examination. Thus, the research will put Coach Carter under the lens of education film to answer the problems in real life.

\section{WHAT DID THEY SAY ABOUT EDUCATION FILM?}

The previous chapter has examined the school film genre. The spotlight from now on will focus on films about teaching, or the educator-heroes movies. Hence, this chapter will take a look at research papers which have been written on the subject of educator-heroes movies. Most of the research 
studied a group of movies as a reflection of education in reality. For instance, $A$ brotherhood of heroes: the charismatic educator in recent American movies (Farber \& Holm, 1994a) or From blackboard to smartboard: Hollywood's perennially misleading teacher heroes (Barlowe \& Cook, 2015) studied a group of education movie in order to find a universal meaning and characteristics shared among those movies or explore the reflection of those movies to a universal problem such as school or teacher. On the other hand, there is a work from Ian Parker Renga (2015), which studied a single movie in an unconventional lens to provide a different view on the narrative and its meaning. Regardless of the differences, the research focused on connecting the portrayal fictions to the reality of education.

Every research looks at education movies in various lens and styles. However, there is a few arguments have been circulated throughout. Most of these movies, while stressing some issues, still misrepresent the reality of teaching, school, and education (Bauer, 1998; Farber \& Holm, 1994a; Barlowe \& Cook, 2015). The portrayals of the teacher, however, were seen as more positive and potentially contributed to the conversation of what is meant to be a teacher (Liston, 2015; Rhem, 2015).

Where did these movies get the reality of teaching wrong? Barlowe and Cook (2015, p. 26) argued that: "Relationships with individual teachers are important, but it is usually the collaborative efforts of several teachers that transforms a given student." Bauer (1998, p. 315) suggested that: "Good teaching turns the primary desire to be liked, or loved, into the recognition of social needs within the classroom: the value of communal work, discipline, even a calling or commitment to change". On the other hand, the image of an educational institution is usually "empty but unavoidable" and beyond the heartwarming relationship between an individual teacher and students is nothing worth thinking about (Farber \& Holm, 1994a). In Dangerous Minds (Smith, 1995), Barlowe and Cook (2015, p. 34) interpreted that Mrs. Johnson never received any support but rigidity and insensitivity from school administrations even though she was a new teacher with no experience and was "literally thrown into the wolves". Bauer (1998) implied that the challenge Mrs. Johnson faced was the dramatic tensions of a violent threat and erotic connection. Mrs. Johnson's story suggested that the teacher will have to rely heavily on their ability and a successful education will require a personal and intimate connection with the students. Indeed, the same narratives can be found in John Keating or Jamie Escalante's story. The simple depictions are considered as the result of the formula that virtually every educator-heroes movies has been followed (Farber \& Holm, 1994a; Bauer, 1998; Barlowe \& Cook, 2015). 
Educator-hero movies are nowhere near perfect but their significant appearances in American popular culture is undeniable. Film critic Roger Ebert never considered education movies close to perfection. He thought Stand and deliver has turned a good story into a corny story, or he questioned the reality of education in Dangerous Minds (Ebert, 1988, 1995). In a review on Teachers (1984), he said: "Here's the sad bottom line: "Teachers" was just interesting enough to convince me a great movie can be made about big-city high schools. This isn't it." (Ebert, 1984). The opinions from the famed film critic suggested the matter of education is worth telling but the movies merely scratched the surface and usually failed to tell something more profound. According to Barlowe \& Cook (2015, p. 37, 38):

[Educator-hero movies] are ideological tools, disguising as entertainment the latest received wisdom on what ails our schools. [...]. Hollywood teacher movies also function more generally as safety values, presenting societal problems in a distorted form that allows them to be misleadingly resolved or conveniently dismissed.

These movies always talk about putting the students under social problems like racism, class priority, bureaucratic authority or even as philosophical as the meaning of life but they always generalized or personalized into one or two people. The way out is also personalized in the effort of our heroes. For instance, Stand and deliver touches upon the matter of racism when all the kids' results were questioned by the Educational Testing Service due to abnormalities. In Dead poets society, Mr. Keating encouraged his students to "seize the day" and "live deep and suck out all the marrow of life" because they are caged inside a dry and robotic environment. All the problems were suggested, however, the solutions were more or less too good to be true. When Escalante and his students had to study during the summer without any air conditioner, he simply reassured them to "think cool" and then everyone happily continued studying with newly fresh motivation. The scene suggested that the charm and charisma of the teachers can help students through anything but such resolutions are so quick, sometimes unclimactic, that they make the audience question if they could really happen in real life?

Even though the "think cool" scene might never work in reality, in a sense, we cannot help but fall for the charm of it. Rhem (2015, p. 23) argued that: "[...] a balance full of passion tempered as much by a love of the past and all that it has to teach as by the future and all that lies ahead in it to be discovered. If the portrayal of teachers in film shows us anything, it shows us that we deeply understand what a real teacher is. We know one, when we see one." This remark suggested one of the 
few things that education movies possibly get right: the teacher. For instance, in Dead poets society, can we have a better feeling about teaching than when Keating covered Todd's eyes and energetically urging him to make a poets or when Keating furiously told the class to rip the essay out because it was too excrement to learn, or when Keating took the boys out of classroom and showed them the history of their school and whispered to them: "Carpe diem"? Education movies are full of moments like these, which provoke in the audience feelings of familiarity and excitement. Liston (2015) suggested that Keating methods are usually seen as progressive in contrast with conservative. Moreover, Farber \& Holm (1994a) also noted that the movies tend to stay in its safe zone with familiarity in stories and characters that we do not challenge ourselves to consider the different possibility and the only reciprocity for the audience is smile when the cinema light turn on. Hence, the effect is that the movies sweeten our reality by provoking the familiarity in the teacher archetype in a better than life story.

\section{PROBLEMS IN EDUCATION MOVIE THAT CAN EXPLORE FURTHER}

Scholars have examined many matters on the subject of education movies and we have taken a look at a few of them. In general, their main focus is the depiction of teaching and teacher, which mostly happens inside an institutional setting; and the general idea behinds the educator-hero genre and its 
contribution. The opinions vary between positivity and negativity but most of the authors believed education movie can be better; even the well-known films such as Dead poets society or Stand and deliver. The problems are the reliance on the formula, the intention to focus solely on an individual effort or the lack of seriousness in stressing problems inside the school.

Most of these research is focus on the teaching, however, there are also other matters and questions can be raised. First and foremost is a deeper focus on the problems inside the school through the filmic depiction, especially inner-city school, and racism is one of the most circulated problems. They are the main conflict in Stand and deliver with Hispanic students or Freedom writer focus on a multiethnicity classroom. Bureaucratic authority is as equally important as racism. School administrations in the film are often depicted as bureaucratic or too task-oriented, such as the principal in Dangerous minds (Smith, 1995) or in Dead poets society, the Educational Testing Service in Stand and deliver. Secondly, the matter of curriculum should be questioned. In these movies, the teachers teach only one subject but it seems like that is enough. For instance, Escalante uses math while Keating, Johnson or Gruwell use literature and poetry. The films caught up in its moments between the teacher and students in their classroom that we come to think one subject is enough for future preparation, others are all superfluous. Finally, what left to be considered is the question of education system efficiency: why does the idea of school is failing in educating kids is always depicted?

The problem of racism or bureaucratic authority inside the school are indeed important and worth exploring, however, they were portrayed in the context of American society and to some extent Western society because most of these movies are Hollywood productions. Even though these problems can be found in different societies, they still require a much larger effort, cultural and social backgrounds to examine thoroughly. Thus, in this paper, I will not go deeper in the above matters due to the limitation in my cultural and social backgrounds.

The matter of curriculum can indeed be explored in the context of social problems but curriculum and its meaning to students are indeed an educational aspect. Almost every person who went through public school system did study basic subjects such as mathematics, literature, history or physics. The content is also similar in a way, especially at the foundational level: in math, we should know about Pythagorean theorem or in history, World War II is a must. However, in the relation with movies, as we have reviewed previously, what should be considered is the importance of curriculum to students 
and what can be taught by the employment of such curriculum. Jamie Escalante believed that his students will have a better chance in life by passing the advanced calculus test. John Keating believed poetry is what makes us human and his students can understand the joy of life through poetry. These education movies mainly use conventional academic subjects as the absolute education that will reciprocate. Is it true?

Sport is not the life-changing subject for students in education movies. The lessons of sports were not believed to be educational, certainly to the sense of conventional education system. Film genre-wise, sports movies is also a separated genre from education movies because education movies talk about school, teacher, and students while sports movies can be outside school. However, Coach Carter was set in high school and the movie's content is about education. Hence, how does Coach Carter reflect the debate between sports and academics in reality? And what does Coach Carter say about the idea of education?

\section{PART II}

\section{DATA INTRODUCTION}

In the previous chapters, I have briefly introduced about the purpose of this research and we have also got to know some background information on the education movies genre, take a look at the subset of educator-hero films and research on these films. Moving on, this chapter will introduce the pool of data, data selection process and why Coach Carter was chosen as the main data before we come to the analysis.

\section{What is sports film?}

Nick Lacey (2009) states that: "[Genres] are a paradigm that producers use to create texts and audiences use to read them. This is most clearly defined as a repertoire of elements consisting of typical narratives, iconography (visual and aural signs), characters and settings." Thus, when speaking of sports film genre, we expect to see characteristics of a conventional sports movie. However, Glen Jones (2008) suggested that there is a certain confusion and hesitation when considering sports films as a definitive genre because its uniqueness mostly lies in the "iconography and recurring visuals motifs" while the story is mainly melodrama. This ambiguity leads to the fact that sports films have been 
considered as more of an entertainment; unless the movies themselves touch upon some serious issues through sports like Raging Bull (1980) or Million-Dollar Baby (2004).

Despite the confusion in defining the genre definitively, there are some signature elements that recurring regularly in the sports films. According to Jones (2008, p. 122):

These elements include firstly, an unknown protagonist. Secondly, the team (or hero) struggles against tremendous odds followed, thirdly, by the unlikely hero needing a love interest to keep him/her inspired. Fourthly, there is a doubt (in the audience and conveyed through the narrative) whether his/her aspirations are achievable, a scenario which lends itself to a dramatic conclusion. Opie continues, indicating that there must be a ritualistic training sequence in order for the challenger to transform into a realistic contender; the contender is nurtured by a grizzly 'glowering older male figure' [...]. Finally, the antagonist, the 'anti-hero', the 'villain', must be defeated.

These elements are the foundations for us to recognize and categorize a movie as a sports movie. However, the element and the genre are more or less a foundational guideline and each specific film requires further consideration. In fact, the above elements are more applicable to a lone sportsman centered movies. Team sports movies, even though share the same structure, contain some elements of educator-hero movies in it: we can find a heroic teacher in a heroic coach, a class in a sports team.

\section{Data Introduction}

Listed below are all the movies I have studied for these research.

\begin{tabular}{|l|l|}
\hline Movies & Director, Year \\
\hline To sir, with love & Clavell, 1967 \\
\hline Teachers & Hiller, 1984 \\
\hline Stand and deliver & Menedez, 1988 \\
\hline
\end{tabular}




\begin{tabular}{|l|l|}
\hline Dead poets society & Weir, 1989 \\
\hline Lean on me & Avildsen, 1989 \\
\hline Dangerous mind & Smith, 1995 \\
\hline Remember the titan & Yakin, 2000 \\
\hline Friday night lights & Berg, 2004 \\
\hline Coach Carter & Carter, 2005 \\
\hline Freedom writer & LaGravenese, 2007 \\
\hline The history boys & Hytner, 2006 \\
\hline Entre les murs (The class) & Cantet, 2008 \\
\hline
\end{tabular}

First of all, the majority of the movies are American. The dominant of American movies due to the fact that I used English as the main research language, thus most of the suggestions I have been able to find are mostly English-speaking movies or movies that are famous to English-speaking audiences. As Barlowe and Cook (2015) suggested, there was a trend in the 80s that many educator-hero movies were produced during this time in America, that make movies like Stand and deliver or Dead poets society became the case studies when considering educator-hero movies.

Secondly, there are only three sports movies in this list because this research started with the main focus on educator-hero movies. It was only until the later that the idea of studying a specific sport movie in the lens of educator-hero movies occurred. In order to maintain the connections among the movies, I tried focusing on the setting in high school, and eventually, Coach Carter became my main research subject.

Finally, there was a limitation in accessing the movies that prevent me from digging deeper into the pool of data, especially the older movies. Hence, I finally settled down with this list, which I believed 
have provided enough background knowledge on educator-hero movies and also the main data is from one film only: Coach Carter.

In the listed movies, the premise or the main concept is similar throughout. They are stories about teacher and student, which make their core storylines share many similarities. However, the designing principle or how the stories are told is what makes Coach Carter standing out and different from others. At the beginning, it started as a normal sports movie with a coach and team struggling to be better. However, the main conflict of the movie revolves around the idea of which is more important: a glory season in high school or a secure place in college and life. Ebert (2005) in his review shared an interesting insight about the main actor Samuel L. Jackson: "Jackson is arguing against the antiintellectual message that success for young black males is better sought in the worlds of rap and sports than in the classroom." In fact, there is a common myth that sport can be the way to the richness and social class, especially in minority populations. Thus, the movie challenges this idea through the story of sport.

\section{COACH CARTER: SYNOPSIS \& A FIRST LOOK}

Coach Carter was released in 2005; directed by Thomas Carter with Samuel L. Jackson as the lead actor. The movie earned around 29 million dollars in its opening weekend and received positive ratings with 7.2/10 on IMDB, $65 \%$ on Rotten Tomatoes and the famous film critic Roger Ebert gave the movie 3 out of 4 stars. Coach Carter was based on the true story of Ken Carter - basketball coach of Richmond High School - in 1999 when he stopped practices and games so his players can improve his academic records. Indeed, there was a proportion of dramatic truth but the movie is believed to tell the most honest version.

\section{Sypnosis}

The movie started when Ken Carter (Samuel L. Jackson) was closing his store and heading to Richmond gym to see the game between Richmond and St. Francis to support his son, Damien Carter (Robert Ri'chard), who was playing for St. Francis. Richmond was losing heavily and there were arguments even within the team. Eventually, they could not keep their hot head and a fight broke out between Ty Crane (Sydney Faison) - St. Francis superstar - and Junior Battle (Nana Gbewonyo) - one

of the senior players of Richmond - which led to the game cancellation. In the locker room, Ken 
Carter received an offer from the old coach to lead the team while there was another fight between Timo Cruz (Rick Gonzalez) and Jason Lyle (Channing Tatum). Ken Carter was unimpressed and disappointed when looking at an undisciplined and hot-headed team but he was also motivated by the challenge that he accepted the offer. His son knew about his new role that made him wanted to move to Richmond and played for his dad.

On the way to Carter's first day as Richmond basketball coach, audiences have a brief look at the neighborhood with street full of thugs and Richmond High School has security check like an airport. The main story finally started from here with the first meeting between Ken Carter and his team. Ken Carter introduced himself as an ex-star of Richmond High and now he would be their coach. He quickly explained the team rules: Training at 3 but late as of 2:55, late equals suicide run and attitudes equal push-up, must call each other "Sir" and finally, a contract. His contract created a mixed atmosphere among the team because it was not about basketball but the main details were academic related: GPA over 2.3, full class attendances, must sit in the front row and wearing a shirt and tie on game day. Worm (Antwon Tanner) and Cruz took it lightly and started joking but Carter quickly showed them who was in charge. Cruz was even more rebellious when he tried to punch Carter but was disarmed. He decided to leave the team, thought the whole thing was a joke, and some players followed him as well. Carter did not waste anytime on those who left and he started the practice right away with a heavy strength and stamina training. After that, the movie took a brief look at Kenyon Stone (Rob Brown), whose girlfriend Kyra (Ashanti) was pregnant.

At this point, the movie has established the main story and 2 side stories which were used as an elaboration. The main story mainly revolves around Coach Carter and his senior players, who were good at basketball but lacking in academic. The first side story was about Kenyon Stone, a brilliant young man but only think about his girlfriend, his baby and a family after graduation. This story provides an insight on how the boys see their future, with and without guidance. The second side story was about Cruz and his process of becoming a man, when Cruz with the influence from his cousin can easily become a drug dealer or a thug in the future.

The movie introduced another conflict between Carter and the community. The community mostly believed that basketball would be the highlight of these boys life so why Carter required too many complexities. The meeting finished with disagreements but Carter's firm and established opinion 
somewhat forced the parents to temporarily agree. Carter's son, Damien, made his own decision to move to Richmond against his father's will. The team started training tactics and finally, they won their first game of the season even though there were still problems. Cruz saw the game and he showed up at the next practice hoping to rejoin the team again; indeed, Carter did not go easy on him and made him do 2500 push-ups and 1000 suicides before Friday. Even though he could not finish it by the deadline but the team, surprisingly, supported him and helped him finish the task. A better team atmosphere was found. However, the continued winning streaks came along with the attitudes from the players when they acted cockier and humiliated their opponents. Carter demanded them to show the sportsmanship, to show some class and act like champions. Along with basketball, Carter also requested weekly academic records on his players but none was given and when he checked, most of them skipped class as well. The teachers, represented through Principal Garrison (Denise Dowse) expected Carter to coach only and demanded him to do his job. Hence, Carter first came to his players and showed them their potentials and a better future in college; he also suspended Junior, because he missed class, as a shoutout to everyone to take his words seriously. After that, Junior and his mom apologized to Carter and promised to be better. Kenyon started to realize what future he does not want and how a baby can make life harder for both him and Kyra at such young age. The team now had their own reputation and won a friendly tournament. As any young players would do, the team party hard and it made Carter furious. Carter deep down wanted the boys to straight up and act out of the conventional sport stars sphere with fame, parties and girls. Later, the reports finally came and it made Carter deciding to employ an extreme method. He locked out the gym, canceled practice and required the boys at the library for studying. Once again, Cruz protested and left.

From this point, the conflict between the coach and the community reached its peak. The boys, however, were still in between. Carter showed the boy the harsh reality of life and encouraged them to see further:

Well let me tell you what I see, I see a system, that is designed for you to fail, now I know that all of you like stats so let me give you some, Richmond high only graduates $50 \%$ of it's students, and of those that do graduate only $6 \%$ go to college, Which tells me when I walk down these halls and look in your class rooms, maybe only one student is going to go to college, Well damn Coach Carter if I ain't going to college where am I going to go? Well that's a great question and the answer for young African-American men in here is this, probably to prison, in this county 
$33 \%$ of black males between 18-24 get arrested, so look at they guy on your left, now look at the guy on your right, one of you is going to get arrested, growing up here in Richmond you're $80 \%$ more likely to go to prison than college, those are the numbers, those are some stats for ya ass, now I want you to go home and look at your life's tonight, look at your parents lives, and ask yourself do I want better, if the answer is yes I'll see you here tomorrow, and I promise you, I'll do everything in my power to get you to college, and to a better life. (Carter, 2005, 01:27:47)

Nonetheless, deep down he was discouraged by the protest from the community and the hardship he was facing. The community believed the lockout would result badly for students because it took away the only thing good for the boys. Moreover, the media attention from the lockout also raising questions regarding teachers' quality. Hence, the request to end the lockout was asked and accepted. As the world against him, Carter decided to quit because he cannot support the message that the community is sending: playing a basketball game is more important than a chance in college and a better future. Along with the main story, Cruz faced a tragedy when his cousin died from a gunshot. He came to Carter and finally realized how his life could possibly turn out and why Carter did what he did. Kenyon found out Kyra did the abortion by herself and he wanted to be there with her. As the community decision, the lockout was ended but the boy made a decision for themselves and fulfilled the contract agreement with Carter. They finally reached their goals and headed to the state championship. Once again, they met their St. Francis. It was an intense and breathtaking game and St. Francis could only win at the last few seconds. Richmond could not fulfill their dream of becoming state champions but they earned respects from the supporters, the opponents and indeed from Coach Carter. The ending note tells us Richmond finally won 5 college scholarships and 6 members went to college.

\section{Coach Carter as a sports movie}

Coach Carter is a sports movie with all the characteristics of the genre. For instance, we have an antagonist: Coach Ken Carter, and a team which was struggling: Richmond Oilers basketball team. The doubt arose concerning the methods and later led to the conflict during the lockout was built up and portrayed skillfully and powerful, especially among Carter and his team. The training rituals, the older male figure or the eventual triumph were merged or avoided. The older male figure is merged into the role of Ken Carter. He is the one who had been through and knows it all, but he also came 
with a new passion for not only winning in basketball but also winning in life. The training rituals did show the improvement and transformation of the team, however, it organically integrated into the story and does not function as a plot device, such as for "the challenger to transform into a realistic contender" (Jones, 2008, p. 122). Finally, the eventual triumph does not lie in basketball but "lives, not games, were won.” (Ebert, 2005).

Glen Jones (2008) considered Coach Carter as one of the few sports movies that achieved both entertainment and seriousness in the final production. He said: "[Coach Carter] skillfully explores the young contemporary black American male experience of attempting to balance sport and education with the realities of living in urban, inner-city Richmond, USA" (Jones, 2008, p. 125). Another feature that makes Coach Carter worth mentioning is high-quality sports sequences, which was choreographed by an expert and executed successfully by the cast, who are all experienced and comfortable with the ball. According to Jones (2008), the only problem is the stereotyped characters. Nonetheless, Coach Carter is still more or less a typical sports movie and it is understandable if the movie follows some conventional and stereotypical formula, especially the biased reactions from the community, the portrayals of the girls or the depiction of school.

Exploring Coach Carter in the sports film genre puts some of the most important characteristics of the movie under the scope, however, under the lens of the education genre, the movie potentially brings another layer to its message. The movie has sent a strong message against the common belief of success can be found in sports but the classroom, especially for African American young men particularly, and minority populations in general. As a sports movie, Coach Carter is entertaining with its wonderful game sequences, a striving-for-glory story with motivational training sequences and thorough insight on basketball and how to be better at it. Nonetheless, the main conflict and its thought provoking moments stay away from the gym but inside the library.

What Ken Carter did as a coach is similar to what Escalante or Gruwell did as a teacher. The intent is identical: helping a group of ethnically minority young men to go to college and a better life. However, why Coach Carter has rarely been considered as an education movie? Is there a priority to academic subjects in education? And is it true that what is academically acceptable is more appropriate in education? 


\section{COACH CARTER AS AN EDUCATION MOVIE}

The first aspect makes Coach Carter an education movie is how the movie follows an education movie formula. Farber and Holm (1994a) suggested the formula for an educator-hero movie with a man with visions tries to connect with students but he meets obstacles that push him to the limit; however the students, at this point, realize the unconditional love and the intent of the man and bring him back; the man finally finds his passion again and continues his quest until his students finally succeed. Similarly, according to Barlowe and Cook (2015, p. 28), the formula is as following:

[...] cast the teacher as a resilient, resourceful individual whose progress is the product of their singular talents; have the teacher lead students through a set of "aha" learning experiences; obscure any positive role played by the school community or culture in developing the hero's skill; conceal the fundamental problems facing schools; and advance whatever false conventional wisdom is being promoted to solve them.

According to the formula, what an education movie need first and foremost is a man with a vision of what needs to be done, who is resilient and talented. Ken Carter is a man as such. At the beginning of the movie, he showed up in a suit and audiences hardly see him without it. The suit strengthens his image as a serious and successful businessman with his own sports store. Moreover, he could only go to the game halfway through after closed his store, which reflects Carter as a responsible and workdedicated person. Later, when the old coach offered him the position, he did not agree right away but gave it some considerations while perceptively weighing the team and the job. His girlfriend, as a loving person to him, saw through the confusion and knew he will take the job no matter what. Later on, he started the first meeting with the team and he firmly established his power and position as a leader. He cared about virtually every aspect of his team: from daily things like speaking or appearance to basketball or life. He requested them to use the word "Sir" as a matter of respect; he wanted them to dress up for the game. There were rules for the training and there was a contract to set up the team's goals. Loud and clear, he said: "Winning in here is the key to win out there." (Carter, 2005, $00: 11: 27)$.

Carter's quest was not a road full of roses, he met struggles too and only the love from his students that helped him through. After all the "aha" learning experiences, especially on the basketball court, 
Carter faced the obstacles, from his students, from the school and from the community. The student, did not fully understand Carter's long-term vision for them, only worked hard on the basketball field and once achieved some glories, they started loosening up. The school expected Carter to coach only. The community believed basketball was the only highlight in their kids' lives so nothing else matter. The peak of the conflict happened when Carter locked the gym and asked the boys to study until they fulfill their contract. The community got furious because of the decision and brought Carter to trial. The board voted to end the lockout, thus, disappointed Carter and led to his decision to quit. His boys, now realize Carter's love and vision for them, sat inside the gym and studied with other teachers to fulfill Carter's wish.

In Carter's quest, the role of the community and culture is negative. They are the main obstacle that Carter had to face until he could reach his goal. The community was depicted as a corrupted town with the ratio of people going to jail is higher than graduated from high school. It was shown through the road that Carter drove to Richmond, in which the thugs were in every corner; and even a supposedly safe place as school utilized heavily security protocol at the entrance. Later, when we met the boys' parents, they were portrayed as an angry group with just basketball in mind when thinking about their kids. This is also the culture of the neighborhood, in which the future is in crime or prison more than anything else. However, there were some lights represented by Junior Battle's mom - who wanted him to play for Carter and saw a future in college for him, or the principal - who at first considered Carter only as coach but then advocated for his effort. In fact, the principal supported Carter in real life (Edwards, 2005).

Against the convention of the genre, Richmond basketball team success was not the product of Ken Carter alone. There were three teachers agreed to help and the team could not reach the goal without them. Nonetheless, their screen time was almost unnoticeable and most of the motivation came from Carter. For instance, besides his energetic speeches, he even asked some girls to show the boys that being smart does matter. Moreover, the movie brings an unexpected ending when Richmond lost to St. Francis. This ending suggested the unpredictable nature of sports where you can lose even though you have played better, but the support from the audience and the eventual success when a great sports performance along with a good academic record gave the team members a ticket to college show the timeless value that a student-athlete can achieve. 
Coach Carter is all about a teacher who taught his students about life. The movie goes against the belief that education can only happen inside classroom and tell us that the education on life can be learnt anywhere. In this case, sports takes an important role but its significance has been obscured.

\section{COACH CARTER AS A REFLECTION ON SPORTS - ACADEMICS DEBATE AND EDUCATION}

Richmond's success is the compilation of outstanding basketball performances and adequate academic record. The team success in basketball was what triggered each member's' college opportunities. Ken Carter believed most of them were able to play in college, and there were scouts coming to the games watching Richmond played. They were good players but at the beginning, they lost pathetically and could not keep their hot heads together. Ken Carter showed up with the emphasis on the conditioning level: stamina and strength. Indeed, at their first game of the season, Richmond won because they could run until the end. After that they sharpen their skills and tactics, even the attitudes during games were fixed. In term of basketball, they became a better team, always kept their minds sharp and played with passion.

During his final locker room speech, Ken Carter said: "I came to coach basketball players, and you became students. I came to teach boys, and you became men." The first game and the last game of the movie, Richmond all lost to the same opponent. But the first one ended up in a fight and the last one finished calmly. The team players were no longer the undisciplined kids we met. The stats showed that 6 members went to college and 5 with a scholarship. This was a foreseeable phenomenon. The academic requirement from Ken Carter is that every player have to achieve 2.3 GPA with full attendance. As he explained to the parent at their first meeting:

If you have a 2.0, you have to score at least 1,050 on the SAT... to be eligible for an athletic scholarship. If you have a 2.3, you only need 950. Now, 2.3 is just a C-plus. It shouldn't be that hard to maintain a C-plus. (Carter, 2005, 00:20:29)

His vision was thoroughly planned based on what was required. However, it was only until Carter packed his stuff that the team took the matter seriously. The academic was often overlooked, especially outside of school context. The community indeed neglected academic when all they think about was 
a glory in a basketball season. Coach Carter represented the reality of a harsh neighborhood where young people have a higher possibility of going to jail than anywhere else and school is more or less an obligation than an actual need. Thus, this lead to the glorification of basketball with the common ideas such as basketball is better than drugs or basketball is the only glory of their life. There is no one considers the fact that "in the county, 33\% of black males between 18 and 24 get arrested." (Carter, 2005, 1:28:32). That is right after high school graduation. Away from sports, the academic has not done any better: Richmond graduated only $50 \%$ of its students every year and higher percentage being girls, that means only 5 out of 15 basketball team players might be able to graduate, not to mention college, as the principal told Carter. Separately, both of them fail at education in the most basic sense. So Coach Carter advocate for a balance between sport and academic, especially to a group of young talented American-African men. The film reflects the debate of cutting down sport in high school, in which a balance is the most circulated suggestion. The debate started with arguments argued that American culturally focused on sport too much, especially at the high school level; thus, there is a need to cut down sport so students can focus on the academic (Ripley, 2013; Smith, 2014). On the contrary, there are arguments suggested the benefit of sport to academic and daily life (Bowen \& Hitt, 2013; Gill 2014). Most of the debaters did not deny the benefits of sports, however, there are people considered American high schools may have gone too far thus a total cut down is necessary while there are people voiced for a close monitor.

In reality, the dominant role of academic in the society is undeniable. College is still the most viable option for a future and it applies to everyone. In Coach Carter or any other education movies, college is the ultimate goal that carries the hope of a brighter future. Outstanding sports performance is needed but an adequate academic record is required. The dominance of academic was created due to the need of the capitalism and industrialism society, in which science, math or language are believed to hold the key to innovation and progress. The education system is narrowed down to only a number of prioritized subject but does not provide an equal education. Scholars have argued that school is wrongly educating our children (Illich, 2002; Gatto, 2005; Postman, 1995; Robinson, 2011). Thus, it is understandable if there are a number of students finding disengagement inside the classroom and seeking relief through sports or arts. In a sense, the debate on cutting down sport in high school was an outcome of a prioritized education system, in which the academic receives more attention. Sports, even though educational, is being considered lightly. 
Coach Carter correctly reflects the dynamic between sport and academic. Sport and academic lie at two different ends of a spectrum and people like Ken Carter who was found in the middle is scarce. Sports rarely find its own ground as a serious academic subject and there is always a disconnection when sport and academic are mentioned together.

\section{PART III}

\section{CONCLUSION}

What is education? Sir Ken Robinson (2011, p. 9, 10) argued that: "Education is not a linear process of preparation for the future: it is about cultivating the talents and sensibilities through which we can live our best lives in the present and create the future for ourselves." In this sense, Coach Carter is about education. The development process of Richmond Oilers as a team and their significant individuals highlights Sir Ken Robinson's notion of education. Each and every member of Richmond had their opportunities to explore their talents and opportunities; and the eventual result did not lie in a game, a season or even a college scholarship but a future beyond. Ken Carter, through basketball, taught his players lessons of discipline, attitude, and teamwork; and through classroom, he taught the lesson of honoring an agreement. The movie tells us that education can be found not only inside the classroom but in anything, if you respect and put your heart into what you do.

Even though the knowledge inside the classroom was never stressed beyond a requirement that needs to be fulfilled but Coach Carter does not strongly support either sport or academic. The movie denies the idea that success in life can be found solely in sport and the student-athlete should also spend time inside the classroom. The movie was made before the sports - academic debate caught public attention; nonetheless, as Ken Carter who loves sports but understands a dream can be broken by the harsh reality, it suggests a more secure option. A scholarship will secure a place in college for any student, and to minority students, it will help them less worry about finances. Moreover, the college will open up different opportunities in the future. In the United States especially, the NBA draft system allows college students to continue playing professional basketball. Otherwise, a college degree will more likely to provide a stable job.

Film is the reflection of our society, and Coach Carter reflects not only the reality of sports in American high school but also the reality of education. Sports are important but not enough. Moreover, the 
exclusion of Coach Carter in education film genre research suggests a priority of academic over sports in term of education. The priority is a systematic problem of public education because it was created to serve industrialism so certain subjects are believed to be more beneficial than others. There are criticisms against the modern education system but to truly break out from the cycle that has embedded into our society is not easy. In Coach Carter or in reality, ascending the system and college are the most viable options for the best futures. Sport may not yet heavily included in the education system but there are ways for those who play sport to ascend the system but it requires efforts not only in the gym but also the classroom.

This paper has been able to address some problems in the modern education system through the representation of a movie, however, there are many points it is lacking. For example, the mentioned movies or the debate mostly belong to American context. Even though the author has analyzed in the most neutral voice but there are characteristics that need a careful explanation such as how sport in high school function in the United States. The attention from the community, school and those who in it themselves are significantly different. Thus, regardless the neutrality that the research is aiming for, the finding may be not applicable to every education system in the world.

In the future, I hope the research can be developed further in a more narrowed context of a certain education system. First of all, the data can be in any form. This paper represents the data from a single movie but other similar research can have more varieties such as news media, statistics, personal interview or mass survey. Secondly, the context would be narrowed down to a country, a city or a school. New theoretical frameworks can be applied to explore the issues and provide high quality analysis (Vuong, 2017; Vuong \& Napier, 2015). Personally, I would hope to continue this research in my hometown or my high school. Finally, as the research title, "I learned all about life with the ball at my feet" - a saying by the famous football player Ronaldinho - I hope this small insight on sports education would contribute a humble opinion on the grand conversation of what education is.

\section{MENTIONED FILMS}

Dangerous minds (1995). Hollywood Pictures.

Dead Poets Society. (1989). Touchstone Pictures

Dazed and Confused. (1993). Gramercy Pictures. 
Entre les murs [The class]. (2008). Haut et Court.

Ferris Bueller's day off. (1986). Paramount Pictures.

Freedom writers. (2007). Paramount Pictures.

Friday night lights. (2004). Universal Pictures.

Lean on me (1989). Warner Bros.

Million dollar baby (2004) Warner Bros.

Raging bull. (1980). Chartoff-Winkler Productions

Remember the Titans. (2000). Jerry Bruckheimer Films.

Stand and Deliver. (1988). Warner Bros.

Teachers. (1984). United Artists.

The breakfast club. (1995). Universal Pictures.

The history boys. (2006). Fox Searchlight Pictures.

This is my father. (1998). Hummingbird Communications Ltd.

To sir, with love. (1967). Columbia Pictures Corp.

\section{REFERENCES}

Barlowe, A. \& Cook, A. (2015). From blackboard to smartboard: Hollywood's perennially misleading teacher heroes. In D. P. Liston \& I. P. Renga (Eds). Teaching, learning and schooling in film reel education (pp. 25 - 40). New York, NY: Routledge.

Bauer, D. M. (1998). Indecent proposals: Teachers in the movies. College English, 60(3), 301-317.

Berg, P. (Director). (2004). Friday night lights [Motion picture]. United States: Universal Pictures.

Bowen, D. H. \& Hitt, C. (2013, October 2). High-school sports aren't killing academics. The Atlantic. Retrieved from_http://www.theatlantic.com/education/archive/2013/10/high-schoolsports-arent-killing-academics/280155/

Carr, D. (2010). On the moral value of physical activity: Body and soul in Plato's account of virtue. Sport, Ethics and Philosophy, 4(1), 3-15. 
Dewey, J. (1916). Democracy and education: An introduction to the philosophy of education. New York: Macmillan.

Ebert, R. (1984, January 1). Review of Teachers. Retrieved May 15, 2017, from http://www.rogerebert.com/reviews/teachers-1984

Ebert, R. (1988, April 15). Review of Stand and deliver. Retrieved May 15, 2017, from http://www.rogerebert.com/reviews/stand-and-deliver-1988

Ebert, R. (1989, June 9). Review of Dead poets society. Retrieved May 15, 2017, from http://www.rogerebert.com/reviews/dead-poets-society-1989

Ebert, R. (1995, August 11). Review of Dangerous minds. Retrieved May 15, 2017, from http://www.rogerebert.com/reviews/dangerous-minds-1995

Ebert, R. (2005, January 13). Review of Coach Carter. Retrieved May 15, 2017, from http://www.rogerebert.com/reviews/coach-carter-2005

Ebert, R. (2005, June 24). Ebert's Walk of Fame remarks. Retrieved May 04, 2017, from http://www.rogerebert.com/rogers-journal/eberts-walk-of-fame-remarks

Edwards, T. L. (2005, January 18). Reel to real: Did Hollywood have its way with Coach Carter's story? Retrieved June 26, 2017, from http://www.mtv.com/news/1495990/reel-to-real-didhollywood-have-its-way-with-coach-carters-story/

Farber, P., \& Holm, G. (1994a). A brotherhood of heroes: The charismatic educator in recent American movies. In P. Farber, E. Provenzo, \& G. Holm. (Eds). Schooling in the light of popular culture (pp. 153 - 172). Albany, NY: State University of New York Press.

Farber, P., \& Holm, G. (1994b). Adolescent freedom and the cinematic high school. In P. Farber., E. Provenzo, \& G. Holm (Eds). Schooling in the light of popular culture (pp. 21 - 39). Albany, NY: State University of New York Press. 
Gatto, J. T. (2005). Dumbing us down: The bidden curriculum of compulsory schooling. Gabriola Island, B.C.: New Society Publishers.

Gill, N. (2014, August 4). Do athletes make better students?. The Guardian. Retrieved from https://www.theguardian.com/education/2014/aug/04/sport-at-university-do-athletesmake-better-students

Illich, I. (2002). Deschooling society. London: Marion Boyars.

Jones, G. (2008). In praise of an 'invisible genre'? An ambivalent look at the fictional sports feature film. Sport in Society, 11(2-3), 117-129.

Lacey, N. (2009). Image and representation key concepts in media studies (2 ${ }^{\text {nd }}$ ed.). New York, NY: Palgrave Macmillan

Linklater, R. (Director). (1993). Dazed and confused [Motion picture]. United States: Gramercy Pictures.

Liston, D. P. (2015). Contending views of teaching in film. In D. P. Liston \& I. P. Renga (Eds). Teaching, learning and schooling in film reel education (pp. 56 - 73). New York, NY: Routledge

Liston, D. P., \& Renga, I. P. (Eds). (2015). Teaching, learning and schooling in film reel education. New York, NY: Routledge.

Menendez, R. (Director). (1988). Stand and deliver [Motion picture]. United States: Warner Bros.

Postman, N. (1995). The end of education: redefining the value of school. New York, NY: Alfred A. Knopf.

Plato. (1945). The republic of Plato. London: Oxford University Press

Reed, J. W. (1989). American scenario: The uses of film genre. Middletown, CT: Wesleyan University Press. 
Renga, I. P. (2015). Exploring the heroic teacher narrative with help from the trickster. In D. P. Liston \& I. P. Renga (Eds). Teaching, learning and schooling in film reel education (pp. 41 - 55). New York, NY: Routledge.

Rhem, J. (2015). The teacher archetype in the movies. In D. P. Liston \& I. P. Renga (Eds). Teaching, learning and schooling in film reel education (pp. 9 -24). New York, NY: Routledge.

Ripley, A. (2013, October). The case against high-school sports. The Atlantic. Retrieved from http://www.theatlantic.com/magazine/archive/2013/10/the-case-against-high-schoolsports $/ 309447 /$

Robinson, K. (2006, February). Do schools kill creativity? [Video]. Retrieved from: https://www.youtube.com/watch?v=iG9CE55wbtY

Robinson, K. (2011). Out of our minds. West Sussex, UK: Capstone.

Steel, M. (1977). What we know when we know a game. Journal of the Philosophy of Sport, 5, 96 - 103.

Smith, E. (2014, October 21). Make Sports an After-School Activity, Not a Competitive Team. The New York Times. Retrieved June 12, 2017, from https://www.nytimes.com/roomfordebate/2014/10/21/taking-sports-out-of-school2/make-sports-an-after-school-activity-not-a-competitive-team

Smith, J. N. (Director). (1995). Dangerous minds [Motion picture]. United States: Hollywood Pictures.

The School of Life. (2015, May 15). PHILOSOPHY - Albert Camus [Video file]. Retrieved from https://www.youtube.com/watch?v=jQOfbObFOCw

Trier, J. D. (2001). The cinematic representation of the personal and professional lives of teachers. Teacher Education Quarterly, 28(3), 127-142.

Weir, P. (Director). (1989). Dead poets society [Motion picture]. California: Touchstone Pictures 
Vuong, Q. H. (2017). The (ir)rational consideration of the cost of science in transition economies. Nature Human Behaviour, 2(1), 5.

Vuong, Q. H., \& Napier, N. K. (2015). Acculturation and global mindsponge: An emerging market perspective. International Journal of Intercultural Relations, 49, 354-367. 